\title{
Execução e efetividade das decisões coletivas na saú- de pública
}

\author{
Implementation and effectiveness of collective decisions on pub- \\ lic health
}

\section{Sybelle Luzia Guimarães Drumond}

Doutoranda em Direito Público e Evolução Social. Mestre em Direito Econômico e Desenvolvimento pela Universidade Cândido Mendes - UCAM. Especialista em Direito Tributário pela UGF. Especialista em Métodos Estatísticos Computacionais pela UFJF. MBA em Gestão Empresarial pela FGV. Graduada em Farmácia-Bioquímica pela UFJF. Rio de Janeiro, RJ-Brasil, email: sybelle.drumond@gmail.com

\section{Resumo}

A mudança do Estado, de liberal para social democrático de direito, permitiu a utilização adequada dos instrumentos jurídicos na relativização de seus institutos. São exemplos disso a produção de provas, a atuação jurisdicional e a concessão da tutela efetiva dos direitos coletivos. A satisfação dos interesses transindividuais, em especial os difusos, resultou no distanciamento entre os interesses públicos e os interesses privados. Os interesses individuais envolvem o âmbito privado, enquanto que os interesses públicos têm o Estado como sujeito de direito; os interesses metaindividuais, que são os transindividuais ou supraindividuais, envolvem a esfera individual, com feições difusa, coletiva e individual homogênea. 
O presente trabalho objetiva discorrer sobre modificações necessárias na efetivação dos novos papéis do Estado e do novo papel do processo civil na efetivação das execuções coletivas.

Palavras-chave: Efetividade. Decisão Coletiva. Saúde pública.

\section{Abstract}

The state change from liberal to social democratic right, provided adequate use of the legal instruments to relativize their institutes. Examples include the production of evidence, the court performance and the granting of effective protection of collective rights. The satisfaction of trans interests, especially diffuse, resulted in the gap between public interests and private interests. Individual interests involve the private sector, while public interests have the state as a subject of law; the metaindividual interests, which are trans or supraindividual, involves the individual sphere, with diffuse, collective and individual homogeneous features. This paper to discuss necessary changes in the effectiveness of the new roles of the state and the new role of civil procedure in the execution of collective executions

Keywords: Effectiveness. Colletive decision. Public health.

\section{Introdução}

A Revolução Industrial foi um grande marco na sociedade mundial. Teve início na Inglaterra na segunda metade do século XVIII e colocou em evidência os direitos transindividuais na medida em que ensejou conflitos de massa.

As ações coletivas têm origem no direito norte-americano. São reguladas por leis extravagantes e incompletas, desprovidas de unidade orgânica. 0 Código de Processo Civil - CPC traz a previsão genérica, sem conter as inovações processuais dos doutrinadores sobre a execução coletiva. 0 procedimento das sentenças condenatórias e execuções coletivas nos direitos individuais homogêneos decorrem das inovações do Código Ibero-americano de Processo Coletivo.

Ao longo do século XX, o direito foi protegido por mecanismos da tutela preventiva e repressiva contra as agressões sofridas em seu exercício. Já o acesso à justiça foi facilitado por normas como a Lei do Mandado de Segurança, a Ação Civil Pública, a Ação Coletiva, a Ação Direta 
de Inconstitucionalidade e outros remédios processuais que facilitaram e facilitam a plena prestação jurisdicional.

O direito coletivo é uma especial categoria de direito material que nasceu da superação entre interesse público e interesse privado, não pertencente a administração pública e nem a indivíduos particularmente determinados. Neste sentido, pertence a um grupo de pessoas, a uma classe, a uma categoria, ou à própria sociedade considerada em seu sentido amplo.

No processo coletivo, é importante estabelecer a diferença entre tutela de direitos coletivos e a tutela coletiva dos direitos.

No Estado Democrático de Direito, a cidadania e a Dignidade da Pessoa Humana buscam a atuação participativa e democrática da sociedade na satisfação dos direitos transindividuais, via acesso à justiça. Ademais, embasam os atos administrativos e a implementação das políticas públicas.

Para que se tenha a efetividade da prestação jurisdicional, no âmbito das tutelas coletivas, há que se observar as normas previstas no Código de Defesa do Consumidor - CDC, a Lei da Ação Civil Pública LACP e o Código de Processo Civil para a plena satisfação da tutela jurisdicional.

A observância dos princípios constitucionais garante um processo democrático de livre arbítrio, alcançando os fins almejados pelo Estado e pela sociedade. Estas garantias processuais positivam o processo na sua efetivação, na busca do alcance da justiça.

Cabe ao Estado proporcionar mecanismos de acesso à justiça que viabilizem a proteção processual dos direitos coletivos. Apesar do Código de Defesa do Consumidor e da Lei da Ação Civil Pública subsidiarem o sistema processual coletivo, ainda se faz necessário um avanço dos operadores do Direito para que se promova a tutela jurisdicional coletiva.

Busca-se uma sociedade com prestação jurisdicional em maior amplitude e com maior celeridade, em contraposição da tutela individual. Como consequência, o Estado despende de menor volume de recursos financeiros no aparelhamento do Poder Judiciário

No que se refere à execução coletiva, apesar de haver alterações recentes no Código de Processo Civil, trazidas pelas Leis 11.232/2005 e 11.382/2006, na efetividade das demandas coletivas, ainda se fazem 
necessárias inovações legislativas para que se alcancem resultados eficazes na resolução dessas demandas.

\section{Direitos coletivos e democracia participativa}

O Estado Democrático de Direito está previsto no art. $1^{\circ}$ da Constituição Federal de 1988 e traça as diretrizes em prol da justiça social. Para José Afonso Silva (2002, p. 120):

O Estado Democrático de Direito é um tipo de Estado que tende a realizar a síntese do processo contraditório do mundo contemporâneo, superando o Estado capitalista para configurar um Estado promotor de justiça social que o personalismo e o monismo político das democracias populares sob o influxo do socialismo real não foram capazes de construir.

No Estado Democrático de Direito, busca-se o cumprimento de proteção garantidos aos cidadãos na tutela preventiva e repressiva. Segundo Falcão (1981, p. 9):

[...] a tutela coletiva é uma realidade legislativa, constatada sua ampliação na Constituição Federal, em decorrência do Estado Democrático de Direito. Nesta direção, a tutela coletiva permite que o cidadão tenha efetividade da atividade jurisdicional, onde o processo coletivo é mais participativo, tanto em razão de ser provocado pelo cidadão, como por ser provocado pela associação ou sindicato dos quais participa, ou mesmo pela abrangência das decisões judiciais.

O Estado Democrático de Direito tem como princípios: a constitucionalidade, a segurança jurídica, a democracia, a igualdade, a legalidade, a divisão dos poderes e a independência do juiz. Cabe ao Estado viabilizar os mecanismos na efetivação dos direitos transindividuais, difusos e coletivos para fazer valer a democracia.

O termo "democracia participativa" veicula a intervenção direta dos cidadãos na gestão do interesse público, correspondendo a "cidadania ativa". Prevista na Constituição Federal de 1988, assegura ao cidadão a participação na atividade legislativa, administrativa e jurisdicional, ou seja, nas decisões políticas. 


\subsection{0 acesso à justiça e o viés jurídico}

Os direitos fundamentais, em especial os difusos ou coletivos, são fundamentos das demandas sociais. Para Cappeletti (CAPPELETTI; GARTH, 1998, p. 9):

O direito ao acesso efetivo tem sido progressivamente reconhecido como sendo de importância capital entre os novos direitos individuais e sociais, uma vez que a titularidade de direitos é destituída de sentido, na ausência de mecanismos para a sua efetiva reivindicação. 0 acesso à justiça pode, portanto, ser encarado como requisito fundamental - o mais básico dos direitos humanos - de um sistema jurídico moderno e igualitário que pretenda garantir, e não apenas proclamar os direitos de todos.

0 acesso à justiça deve se fundamentar na máxima efetividade dos direitos individuais e coletivos pautado na democracia, com a busca de procedimentos processuais céleres e eficazes. Importa ressaltar que "acesso à justiça" difere do "acesso ao judiciário", haja vista que este último objetiva a proteção de bens de natureza difusa ou coletiva e ao atendimento de um número indeterminado de pessoas.

A eficácia no processo coletivo é importante para a resolução de demandas que envolvem a grande massa da sociedade. A legitimação para agir nestes processos se dá pelo Ministério Público, Defensoria Pública, ou por um ente especializado em determinada área.

Grinover (1998, p. 118-119) acrescenta:

(...) São carentes organizacionais as pessoas que apresentam uma particular vulnerabilidade em face das relações sócio-jurídicas existentes na sociedade contemporânea. [...] consumidor nas relações de consumo; usuários dos serviços públicos; [...] Todos aqueles, enfim, que no intenso quadro de complexas interações sociais [...], maior atenção com relação a seu acesso à ordem jurídica justa e à participação por intermédio do processo (...). 
Não se dissocia democracia de acesso à justiça. A efetivação do processo corresponde a um novo método de pensamento que confere à ciência jurídica uma nova dimensão conceitual e impõe uma revisão completa nos modelos clássicos da metodologia.

0 texto constitucional ao permitir o amplo acesso à justiça maximiza a eficácia dos direitos e garantias individuais e coletivas. Ainda há a necessidade de alterações legislativas para que as demandas processualistas coletivas contemporâneas sejam resguardadas.

\section{0 processo coletivo}

A ação coletiva tem origem no direito norte-americano e tutela os direitos coletivos frente ao indivíduo. As sentenças condenatórias e execuções coletivas nos direitos individuais homogêneos advêm das inovações trazidas pelo Código Ibero-americano de processo coletivo.

É importante esclarecer a diferença entre a defesa de direitos coletivos com defesa coletiva de direitos individuais. ${ }^{1}$

A doutrina e a jurisprudência dividem o processo de conhecimento coletivo entre o de liquidação e o de execução individual. No processo coletivo não há limitação no número de interessados e a sentença condenatória resulta em inúmeras liquidações e execuções individuais.

\subsection{A Contribuição Político-Social da Tutela Coletiva}

O reconhecimento dos direitos coletivos, difusos, individuais e homogêneos faz com que o Estado se organize para melhor proporcionar um meio processual eficaz. 0 processo se torna instrumento de reivindicação dos sujeitos coletivos ao acesso à justiça. A atuação coletiva em muito aprimora a sua função democrática.

Ademais, segundo Marinoni (2008, p. 77-78):

1 Direitos Coletivos são subjetivamente transindividuais (sem titular determinado) e materialmente indivisíveis. Como direitos transindividuais têm-se o difuso e o coletivo stricto sensu. Já os direitos individuais homogêneos são direitos subjetivos individuais, são os mesmos direitos comuns e afins do que trata o artigo 46 do CPC, incisos II e IV. Disponível em: http://www.planalto.gov.br/ccivil_03/leis/15869.htm 
(...) Não basta pensar em direito de defesa, direito de proteção ou mesmo estabelecer direitos sociais. É também necessário conferir aos cidadãos a possibilidade de participação na vida social - por meio dos canais legítimos - para que os direitos sejam realmente respeitados pelo Poder Público e pelos particulares (...).

Acrescenta Grinover que a participação mediante a justiça resulta na própria utilização do instrumento do processo como veículo de participação democrática. Ainda sob o seu ponto de vista a efetivação da prestação da assistência judiciária reputa os meios de legitimação para agir. No plano processual, se insere a democracia participativa por intermédio da participação popular no processo.

A Lei de Ação Civil Pública, o Código de Defesa do Consumidor não sustentam a tutela digna. Já que não há no sistema processual uma legislação específica que tutele os direitos coletivos.

As políticas sociais uniformizam os julgamentos e aumentam a credibilidade dos órgãos jurisdicionais e do Poder Judiciário, na medida em que conferem maior segurança jurídica. Com as motivações sociais, tem-se as demandas em massa, que precisam ser urbanizadas e globalizadas.

O Poder Judiciário, no que se refere às questões de política e de economia, tem significativa atuação na efetivação das políticas públicas, no fortalecimento dos grupos sociais e no impacto das ações coletivas sobre o orçamento das finanças públicas, concorrência e mercados. Toda a intervenção na política pública refere-se ao direito contemporâneo.

\subsubsection{A Eficácia Político-social da Tutela Processual Coletiva}

A satisfação dos direitos sociais está prevista no art. $6^{0}$ da Constituição Federal. A reivindicação pelos direitos da criança, do adolescente e dos idosos potencializa as ações coletivas.

A Lei de Ação Civil Pública e o Código de Defesa do Consumidor são veículos normativos que atendem as demandas no processo coletivo. Mas ainda há entraves na efetividade deste processo. 
Para que se tenha a tutela adequada dos direitos e interesses coletivos, seja no aspecto formal ou material, o sistema processual necessita interpretar as normas com eficiência. A eficaz representação política no processo coletivo se dá pela legitimação de agir na participação democrática da sociedade nos fatores políticos sociais.

As instituições públicas, sob o ponto de vista do direito contemporâneo, devem dar maior representatividade aos sujeitos coletivos como partes do processo. 0 acesso à justiça e a efetivação dos direitos ainda estão relacionados à vontade coletiva.

A priorização dos direitos coletivos é fundamental para a sociedade e promove na redução das desigualdades sociais, que é um dos objetivos do Estado Democrático de Direito, principalmente no que se refere ao acesso à justiça no enfoque das demandas coletivas.

Ademais, as demandas coletivas na sociedade massificada reconhecem os titulares de direitos fundamentais e os procedimentos a serem realizados na efetivação das garantias previstas na Constituição Federal.

\subsection{O papel do juiz nas demandas Coletivas}

A atuação juiz no processo tem a sua origem na experiência americana denominadas class actions, as quais decorrem do interesse público que também pode ser considerado faceta do impulso oficial. 0 juiz induz os legitimados a usar a ação coletiva como instrumento concretizador de seus direitos. Tal previsão está no Anteprojeto de Código de Processo Coletivo do IBDP e na Lei de Ação Civil Pública. ${ }^{2}$

Neste sentido, cabe ao magistrado realizar o controle da efetividade no processo coletivo, facilitando o acesso à justiça e à prestação efetiva da tutela jurisdicional.

\subsection{A efetividade no processo coletivo}

A obtenção da sentença de mérito corresponde a "declaração imperativa de que ocorreu um fato ao qual a norma vincula um efeito jurí-

\footnotetext{
2 Art. 17 da Lei 7.347/85 disponível em http://www.planalto.gov.br/ccivil_03/LEIS/L7347orig.htm
} 
dico" (CARNELUTTI, 1986, p. 69). O alcance do resultado de uma demanda judicial no processo de conhecimento considera a análise das normas de acordo com a sua existência ou inexistência.

No entendimento de Pontes de Miranda (1974, p. 27): "nas ações de cognição (...) há enunciados sobre incidência (toda a aplicação da lei é enunciado sobre incidência)". Isso justifica o posicionamento do juíz sobre o enquadramento da norma abstrata ao caso concreto. 0 juíz declara a existência ou inexistência da relação jurídica postulada pelo demandante, ao realizar os procedimentos de:

(i) exame das provas sobre a incidência ou não do fato;

(ii) verficação do ajuste da norma ao caso concreto;

(iii) ao declarar os efeitos jurídicos da incidência da norma.

Barbosa Moreira (1982, p. 49) acrescenta:

(...) formula o juiz a norma concreta que deve disciplinar a situação levada ao seu conhecimento. (...) a sentença passe em julgado, perdura indefinidamente, excluídas a possibilidade de vir a emitir- se outra norma concreta e a relevância jurídica de qualquer eventual contestação ou dúvida(...)".

A sentença nas ações coletivas é genérica, desta forma, necessita de posterior complementação na satisfação da fase executiva. 0 juízo se dá apenas alguns dos elementos da relação jurídica concreta, e não sobre todos eles.

Segundo Zavascki (2003, p. 320):

“(...) As situações de iliquidez são de variado grau. Considerando-se título apto a ensejar a tutela executiva o que traz representação documental de uma norma jurídica concreta da qual decorra uma relação obrigacional, há de haver nele afirmação a respeito de (a) ser devido (an debeatur), (b) a quem é devido (cui debeatur), (c) quem deve (quis debeat), (d) o que é devido (quid debeatur); e, finalmente, (e) em que quantidade é devido (quantum debeatur). [...] demandas promovidas por substituto processual, para tutelar direitos subjetivos individuais, a sentença condenatória define os elementos (a) (an debeatur), (c) (sujeito passivo) e 
(d) (prestação) sem, no entanto, fazer juízo específico sobre o valor devido (quantum debeatur) e nem sobre a identidade do titular do direito (cui debeatur). São dessa espécie as sentenças proferidas em ação coletiva para tutelar direitos individuais homogêneos de consumidores (Lei 8.078/90, art. 95), em demandas promovidas pelo Ministério Público para obter ressarcimento de danos causados a titulares de valores mobiliários e investidores do mercado de capitais (Lei 7.913/89, art. $2^{\circ}$ ), ou para obter a condenação de ex-administradores de instituições financeiras submetidas a regime de intervenção, liquidação extrajudicial ou falência (Lei 6.024/74, art. 49), em demandas promovidas por entidades associativas e sindicais, para tutela de direitos de seus associados e filiados (CF, art. 5. ${ }^{\circ}, \mathrm{XXI}$, e art. $8^{\circ}$, III) e, em certos casos, as proferidas em mandado de segurança coletivo ( $\mathrm{CF}$, art. $\left.5^{\circ}, \mathrm{LXX}\right)$, quando reconhecer direito a vencimentos e vantagens pecuniárias (Lei 5.021/66, art. $1^{\circ}$ ) [...].

\section{Para Cintra, Grinover e Dinamarco (2001, p. 34-35):}

(...) Para a efetividade do processo, ou seja, para a plena consecução de sua missão social de eliminar conflitos e fazer justiça, é preciso, de um lado, tomar consciência dos escopos motivadores de todo o sistema (sociais, políticos, jurídicos.); e, de outro, superar os óbices que a experiência mostra estarem constantemente a ameaçar a boa qualidade do seu produto final. Esses óbices situam-se em quatro "pontos sensíveis", a saber: a) a admissão ao processo (ingresso em juízo).; b) o modo-de-ser do processo.c) a justiça das decisões.d) a utilidade das decisões (...).

0 resultado do processo deve coincidir com os direitos demandados. A efetividade do processo serve de alerta contra as normas ou interpretações que limitam a efetivação das medidas judiciais.

Há que se buscar métodos que tornem os direitos efetivos. Neste sentido, a doutrina e jurisprudência modernas analisam o processo numa perspectiva teleológica, com a implementação da tutela jurisdicional adequada e diferenciada em cada situação de vida e o tipo de tutela.

O processo civil brasileiro possui uma grande preocupação com as tutelas individuais. No momento em que a busca pela justiça social cresce, para atender às necessidades de toda coletividade, faz-se neces- 
sário adequar o processo civil ao novo modelo, devendo ser modificados os dogmas e relativizados os institutos.

Em sentido amplo, a efetividade das ações coletivas garante à prestação jurisdicional justa, célere e efetiva ${ }^{3}$. 0 processo coletivo é um direito fundamental inerente à coletividade e demanda uma maior atenção dos legisladores ao elaborar tais normas.

A celeridade é um instrumento de efetividade dos direitos fundamentais que não depende somente de questões jurídicas.

As liquidações e execuções coletivas são processadas no juízo da sentença condenatória ou no foro local onde se encontram os bens sujeitos a expropriação.

Com a procedência da ação civil pública ou coletiva, o titulo judicial favorecerá todo o grupo ou classe de indivíduos lesados, nos termos do limite do pedido e do decisium. A sentença do processo coletivo cria um titulo executivo judicial limitado ao pedido judicial.

Em demandas coletivas, não há necessidade de processo autônomo de execução nas sentenças condenatórias, de obrigação de fazer, de não fazer, de entrega de coisa ou de pagar quantia certa.

Os direitos fundamentais não se referem somente ao indivíduo, mas aos direitos inerentes à própria estrutura do Estado.

A EC $n^{\circ} 45 / 2004$ possui eficácia limitada e propiciou as devidas reformas no Código de Processo Civil, em relação à efetividade do processo e à satisfação dos anseios da coletividade de maneira rápida, eficaz e justa.

As ações coletivas são uma realidade em nosso ordenamento jurídico. 0 tema evolui constantemente e esses estudos têm influenciado a mentalidade de nossos julgadores.

\section{Execução coletiva}

A execução coletiva envolve direitos difusos, coletivos e individuais, porém inexiste no ordenamento jurídico uma norma que regulamente este procedimento. Aplicam-se de forma subsidiária os procedimentos previstos no CPC, nos casos em que não contrariar o microssis-

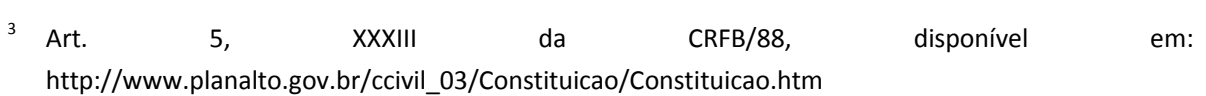


tema de tutela jurisdicional coletiva comum ${ }^{4}$ ou outras disposições específicas, de forma a não colocar em risco o direito material coletivo.

As recentes reformas do CPC, tanto no cumprimento de sentença ${ }^{5}$, como em relação à execução de títulos executivos extrajudiciais ${ }^{6}$, não previu a resolução de questões no âmbito da execução coletiva.

Tanto o Código-Modelo de Processos Coletivos para IberoAmérica como o Anteprojeto de Código Brasileiro de Processo Coletivos não deram tratamento específico e cuidadoso à execução coletiva. Isto justifica a aplicação por analogia de diversas fontes normativas, principalmente do direito constitucional à tutela jurídica ampla, irrestrita, efetiva tempestiva. ${ }^{7}$

\subsection{Aplicabilidade do CPC na Execução Coletiva}

A aplicabilidade do CPC na execução coletiva8 deve ser subsidiária, condicionada e limitada. 0 processo de execução nas ações coletivas possui características que fogem do processo comum. Os mecanismos normativos oferecem meios, formas e, acima de tudo, subsídios importantes ao julgador para uma melhor efetividade de suas decisões.

A execução coletiva de títulos assecuratórios dos direitos individuais homogêneos possui a vantagem da efetividade do processo nos casos de inércia dos beneficiários. Nestes casos, deverá a liquidação ser realizada pelo valor global, assegurando os direitos dos habilitados. $\mathrm{Na}$ execução provisória é prescindível a prestação da caução.

0 Anteprojeto do Código de Processo Coletivo 9 é insuficiente para libertar o direito processual coletivo, na sua condição de um novo

\footnotetext{
4 Art. 21 da Lei 7.347 e o art. 90 do CDC. A execução no plano dos direitos individuais homogêneos está prevista nos arts. 95 a 100 do CDC. Em relação aos direitos difusos e coletivos não há disciplina normativa própria e específica, salvo as previstas nos arts. 13 e 15 da LACP

5 Leis $10.444 / 2002$ e $11.232 / 2005$

Lei $11.382 / 2006$

Art. 5으, XXXV, LXXVIII, e seu § 1ㅇ, da CRFB88

8 Prevista na Lei no 7.347/85, Lei no 4.717/65 (Lei da Ação Popular e na Lei no 8.429/92, Lei de Improbidade Administrativa.

99 A execução coletiva recebe tratamento nos arts. 2ㅇ, 15 e 16, 21, § 3ㅇ, 26, 27, 35, 36 e 37 do Anteprojeto do Código Coletivo. Em geral, salvo algumas inovações, o tratamento reproduz a orientação já presente no Código de Defesa do Consumidor, previstos nos arts. 96 a 100. Disponível em http://www.planalto.gov.br/ccivil_03/LEIS/L5869compilada.htm
} 
ramo do direito processual, das amarras liberais individualistas do processo civil.

\subsection{Execução coletiva em relação aos direitos difusos}

Nos direitos difusos ${ }^{10}$ não há relação jurídica de base, o vinculo ocorre por circunstâncias fáticas, ao passo que nos direitos coletivos em sentido estrito torna-se importante a existência de prévia relação jurídica base entre os membros da categoria, classe ou grupo de pessoas ou entre essas pessoas e a parte contrária.

A legislação brasileira, infelizmente, não possui recursos adequados para a efetivação desses direitos, com base nos procedimentos executivos do CPC. ${ }^{11}$

A execução, no plano dos direitos ou interesses difusos, poderá ser provisória ou definitiva. ${ }^{12}$

Nas sentenças que fixem obrigações específicas de fazer ou não fazer ou de dar coisa certa ou incerta, a execução poderá ser determinada de ofício pelo juiz. Nesses casos, a ação coletiva é de força dúplice.

$\mathrm{Na}$ conversão da obrigação específica fixada, judicialmente, em perdas e danos, ou de condenação judicial em obrigações de dar quantia ou, nas hipóteses das multas fixadas judicialmente, a execução coletiva observará, em regra, o procedimento previsto nos arts. 475-I e 475-R do $\mathrm{CPC}$, no que for compatível.13

10 Interesses ou direitos difusos, assim entendidos, para efeitos deste Código, os transindividuais, de natureza indivisível, de que sejam titulares pessoas indeterminadas e ligadas por circunstâncias de fato. Previsto no art 81, pu, I, do CDC

11 A Lei no 7.347/85 traz três dispositivos sobre a matéria que são o art. 5ㅇ, § 6ㅇ, que prevê a tomada, pelos órgãos públicos legitimados, do compromisso de ajustamento de conduta às exigências legais, conferindo-Ihe força de título executivo extrajudicial. $\mathrm{O}$ art. 13, que trata dos Fundos estaduais e federais dos Direitos Difusos ou Coletivos. O art. 15, que dispõe sobre a obrigatoriedade da execução coletiva pelo Ministério Público.

12 O art. 14 da LACP, que estabelece que os recursos das decisões proferidas na lei ação civil pública serão recebidos, em regra, somente no efeito devolutivo, confirma a possibilidade de execução provisória da sentença nos processos coletivos em geral.

13 O valor resultante da execução será revertido para o fundo dos direitos difusos e coletivos, federal ou estadual, criado pelo art. 13 da LACP. Esse fundo está disciplinado no plano federal pela Lei 9008/1995. Contudo, quando se tratar de reparação de dano ao erário, aplica-se o disposto no art. 18 da Lei 8.429/92, revertendo-se o valor da condenação para a pessoa jurídica prejudicada pelo ilícito. 
A execução coletiva por ação em processo autônomo seguirá o procedimento previsto para a respectiva obrigação a ser executada. ${ }^{14}$

Deve o juiz tomar todas as medidas executivas, coercitivas ou preventivas, visando a efetivação concreta do direito difuso reconhecido no título executivo, estando autorizado a determinar o cumprimento imediato das obrigações do respectivo título. ${ }^{15}$

\subsection{Execução coletiva ns direitos coletivos em sentido estrito}

No plano dos direitos ou interesses coletivos, ${ }^{16}$ são idênticas as regras da execução coletiva dos direitos ou interesses difusos, na transferência in utilibus da coisa julgada coletiva para o plano individual, nos termos do art. 103, § $3^{\circ}$, do CDC.

Nas condenações em perdas e danos a direito coletivo em sentido estrito, ou a fixação de multa judicial pelo descumprimento da respectiva decisão, o resultado da condenação ou multa será destinado, em regra, ao fundo criado pelo art. 13 da LACP, estadual ou federal, conforme o caso.

\subsection{Execução coletiva nos direitos individuais homogêneos}

Os direitos individuais homogêneos, ${ }^{17}$ no plano processual, são uma criação técnico-jurídica do direito positivo brasileiro para possibilitar a proteção coletiva dos direitos individuais subjetivos clássicos.

A jurisprudência não tem compreendido a distinção correta entre as categorias de direitos coletivos adotadas pelo CDC.18

14 Aplica-se o princípio da especialidade dos procedimentos executivos (art. 573 do CPC). Na execução autônoma das obrigações de fazer ou não fazer aplica-se o art. 632 e seguintes do CPC; nas obrigações de dar quantia certa aplica-se o art. 646 e seguintes do CPC; nas obrigações de dar coisa certa ou incerta, tem-se o art. 621 e seguintes; na execução de multa fixada liminarmente, pelo diálogo das fontes, aplica-se o disposto no art. 461 do CPC, pois têm melhor eficácia social do que o art. 12, § 2으, da LACP, já que este exige o trânsito em julgado da decisão favorável ao autor para que se possa promover a execução da multa respectiva

15 Estabelece o art. 66 da Lei 8.884/94, aplicável às execuções coletivas em geral por força dos arts. 83 do CDC e 21 da Lei 7.347/85.

16 Regulados pelo art. 81, parágrafo único, inciso II: os transindividuais de natureza indivisível de que seja titular grupo, categoria ou classe de pessoas ligadas entre si ou com a parte contrária por uma relação jurídica base.

17 Previstos no art. 81, pu, III do CDC. Disponível em: http://www.planalto.gov.br/ccivil_03/LEIS/L8078.htm 
A execução, no que tange aos direitos individuais homogêneos, poderá ser individual ou coletiva. ${ }^{19}$

A legitimidade engloba todos os legitimados coletivos do art. 82 ou do art. 5 da LACP, pois também existe a tutela reparatória a danos a outros direitos ou interesses individuais homogêneos que não os decorrentes das relações de consumo.

A execução coletiva é uma atividade complementar do processo de conhecimento e o produto resultante da execução será destinado às respectivas vítimas ou seus sucessores. Ela pressupõe a existência de liquidação de sentença promovida pelos interessados individuais.

A execução coletiva que se destina à reparação fluida (fluid recovery), disciplinada no art. 100 do CDC, trata das hipóteses de que os interessados poderiam se habilitar perante o fundo para buscar suas indenizações individuais. Shimura sustenta que se o demandado já pagou pela indenização devida, não há razão para exigí-la do devedor, sob pena de violar a proibição do bis in idem. Em sentido contrário está o entendimento de Venturi, o qual sustenta que a única hipótese em que o sistema admite a habilitação de credor individual perante o fundo e, mesmo assim, amparado em decisão confirmada pelo tribunal, está regulamentada no art. 99 do CDC.

Em se tratando de tutela ressarcitória, na forma específica a direitos individuais homogêneos, a execução seguirá o art. 461 ou 461-A do $\mathrm{CPC}^{20}$ quando a obrigação estiver amparada em sentença judicial, ou o art. 621 e seguintes ou, ainda, o art. 632 e seguintes, todos do CPC, quando a obrigação específica respectiva estiver reconhecida em título executivo extrajudicial.

18 CDC, art. 81, pu, I,II, e III. Disponível em: http://www.planalto.gov.br/ccivil_03/LEIS/L8078.htm

19 Arts. 95 ao 100 do CDC. $O$ art. 97 do CDC dispõe: "A liquidação e a execução de sentença poderão ser promovidas pela vítima e seus sucessores, assim como pelos legitimados de que trata o art. 82".

20 O art. 461 ou 461-A do CPC na obrigação estiver amparada em sentença judicial, ou 621 e seguintes ou, ainda, 632 e seguintes, todos do CPC, quando a obrigação específica respectiva estiver reconhecida em título executivo extrajudicial. 


\subsection{Obrigação de fazer e não fazer nas Execuções Coletivas}

As regras para o processo coletivo no cumprimento de sentença são análogas à da liquidação. ${ }^{21}$ Não somente o autor da ação de conhecimento em processo coletivo poderá exigir o cumprimento da sentença executiva, mas também o substituto processual do grupo lesado.

Não cabem embargos do executado na etapa de cumprimento de sentença. Diante da objeção ao réu deverá ser veiculada incidente de impugnação, ao qual será oponível Agravo de Instrumento. A impugnação deverá versar sobre:

a) matérias conhecidas de oficio (falta de pressuposto processual ou condição da ação);

b) matérias argüidas pela parte (inexigibilidade do título ou qualquer causa impeditiva, modificativa ou extintiva da obrigação);

c) defeitos na execução (penhora incorreta, avaliação errônea ou excesso de execução).

]Os embargos à execução e a ação autônoma são cabíveis nas ações por títulos executivos extrajudiciais.

A execução específica é o meio mais eficaz para tornar efetiva a decisão do julgador.

\subsection{Execução provisória na execução coletiva}

Aplicam-se as regras do Código do Processo Civil. 0 mandado de segurança coletivo, salvo nos casos de concessão da medida liminar, não é cabível contra a Fazenda Pública.

\footnotetext{
${ }^{21}$ a) Interesses invidividuais homogêneos e interesses coletivos: o lesado e seus sucessores poderão prover o cumprimento da sentença na parte que lhes couber;

b) Interesses difusos: a sentença de procedência cria um título executivo em favor de todos os colegitimados ativos que se beneficiam de forma indivisível os titulares do interesse material, transindividualmente considerados. $\mathrm{O}$ cidadão somente poderá promover o cumprimento de sentença proferida em ação civil publica em defesa dos interesses difusos caso o objeto da condenação dispor sobre a proteção de interesse que poderia defender na qualidade de cidadão;

c) execução contra a fazenda pública segue as regras do artigo 730 e 741 do CPC.
} 
A execução da sentença transitada em julgado é definitiva, no entanto, a execução será provisória quando se tratar de sentença impugnada mediante recurso ao qual foi atribuído efeito suspensivo.

0 adiantamento da tutela é execução provisória, por conta e responsabilidade do exeqüente, obriga a reparar os danos que a parte contrária tenha sofrido.

\subsection{Execução do Titulo Executivo Extrajudicial e os embargos}

O Termo de Ajustamento de Conduta - TAC, ${ }^{22}$ têm eficácia de titulo executivo extrajudicial, permitindo a execução forçada contra a Fazenda Pública. Nas obrigações de fazer e não fazer de titulo executivo extrajudicial, o juiz fixará multa por atraso no cumprimento da obrigação, bem como a data a partir do qual será devida.

0 art. 475-I e o art. 741, VI do CPC permitem suscitar a prescrição, desde que superveniente à sentença.

\section{Areforma do processo civil em prol da coletivação}

0 acesso à justiça de forma massificada é importante para que se tenha o atendimento ao litígio coletivo, o que justifica a proposta da reforma do CPC, no atendimento da coletivização dos litígios.

0 incidente de coletivização nos litígios de massa objetivam a redução do trabalho no judiciário de forma a não influir na qualidade da prestação jurisdicional. Com origem no Direito Alemão, possui redação na Resolução de Demandas Repetitivas. ${ }^{23}$

No incidente de Resolução de Demandas Repetitivas ${ }^{24}$ a admissibilidade se dá ao identificar uma controvérsia que gere multiplicação

21 Art $5, \quad \S 6^{\circ}$ da Lei $7.347 / 1985 . \quad$ Disponível em:
http://www.planalto.gov.br/ccivil_03/LEIS/L7347orig.htm

${ }^{23}$ São instaurados pelo Tribunal local, por iniciativa do Juíz, do Ministério Público, das partes, da Defensoria Pública ou mesmo pelo próprio Relator. Caberá o juizo de admissibildiade e de mérito ao próprio tribunal pleno ou ao órgão especial. Deverá ser julgado no prazo de seis meses, exceto os que envolvem réu preso ou pedido de habeas corpus.

22 Regulado pelos art. 895 ao 906 do CPC. Disponível em: http://www.planalto.gov.br/ccivil_03/LEIS/L5869compilada.htm, 
de processo com idêntica questão de direito ou que cause grave insegurança jurídica.

Com o julgamento do incidente, a tese jurídica é aplicada a todos os processos que versem sobre idêntica questão de direito, sob pena de reclamação ao Tribunal competente.

Caso a sentença coletiva não contribua para os deslinde das ações individuais, a sua admissibilidade carecerá do interesse processual na tutela coletiva. Neste sentido acrescenta GONÇALVES (1992):

(...) Embora os textos normativos sugiram que a sentença genérica da ação coletiva tem natureza condenatória (v.g. art. 95 do CDC), esta afirmação merece reservas, especialmente quando se tem por parâmetro os padrões tradicionais que informam o conceito de condenação. [...] Assim, adota-se a classificação doutrinária (sentenças condenatórias, constitutivas e declaratórias), [...] no que se refere a demandas envolvendo responsabilidade por dano, é significativa a corrente doutrinária segundo a qual a qual a "sentença condenatória genérica" não é tipicamente condenatória, mas, sim, declaratória, o que com redobrada razão, vale para a sentença genérica da ação coletiva, envolvida em grau de generalidades que qualquer outra (...).

Ademais, segundo Fredie Didier Jr e Hermes Zaneti Jr (2008, p. 183-184):

(...) A jurisprudência poderia, de maneira criativa, dando concreção aos direitos fundamentais da efetividade da tutela jurisdicional, da duração razoável do processo e da segurança jurídica, encaminhar-se no sentido de reconhecer como de interesse público (...) Trata-se de uma exigência de ordem pública, não só decorrente da necessária racionalização do exercício da função jurisdicional, como forma de evitar decisões diversas para situações semelhantes, o que violaria o princípio da igualdade. A aplicação dessa regra, permitindo a suspensão dos processos individuais por prejudicialidade, conforme o dispositivo do art. 265, IV, a, do CPC, já foi utilizada com sucesso em diversos precedentes do Rio Grande do Sul no caso de expurgos inflacionários de poupança. Trata-se de evidente aplicação do princípio da adequação e da flexibilização dos procedimentos aos processos coletivos (...). 
No Estado Democrático de Direito, o procedimento participativo constitui-se na maneira mais democrática para que seja construída uma participação igualitária, paritária, simétrica, que a todos beneficie.

A grande expectativa que se tem na aprovação do código de processo civil coletivo refere-se a garantia de participação das partes no processo decisório.

\section{Considerações finais}

Diante do exposto, observa-se a importância do Direito como instrumento transformador da realidade social, em especial nas questões coletivas com grande relevo social.

Os entes coletivos, no contexto atual, possuem grande relevância e seu reconhecimento como sujeitos titulares de direitos fundamentais. o Estado Democrático de Direito ao proporcionar a inserção dos sujeitos coletivos no ordenamento jurídico assegura a sua participação democrática no amplo acesso a ordem jurídica justa.

Apesar das grandes mudanças sociais observa-se que a efetivação do processo coletivo ainda é um problema para o acesso à justiça. Neste sentido, a Constituição Federal vigente fundamenta as garantias individuais e coletivas pelo princípio da dignidade da pessoa humana, que corresponde a uma dos valores do Estado Democrático de Direito.

Ainda que se tenha o entendimento de que há no ordenamento jurídico brasileiro instrumentos para a efetivação dos direitos coletivos, observa-se que a sua aplicação concreta depende da manutenção de ideologias e institutos da tutela individual.

No que se refere ao âmbito dos direitos transindividuais, busca-se um modelo subsidiado pelos direitos fundamentais da Constituição Federal.

A consciência de que o modelo presente no Código de Processo Civil não atendia à resolução das novas demandas coletivas, surgidas no Judiciário, propiciou a aplicabilidade subsidiária de outras normas infraconstitucionais.

As inovações trazidas pelo Anteprojeto de Código Brasileiro de Processos Coletivos permitem ao juiz a aferição de como o autor da ação coletiva representa os interesses defendidos em juízo. Para os doutrinadores brasileiros as associações que representam grupos pos- 
suem legitimidade de agir, desde que possuam credibilidade, seriedade, conhecimento técnico-científico e capacidade econômica na produção da defesa processual adequada.

A execução coletiva deve ser amparada pela flexibilização de técnicas executivas, aplicando-se de forma subsidiária o CPC, na execução coletiva.

A execução do processo coletivo ampliou a legitimação, a competência e o relevo das obrigações de fazer ou não fazer, como forma específica de cumprimento dos julgados. Na execução específica atende-se à plenitude da satisfação do julgado, assegurando resultado prático equivalente ao adimplemento.

Em relação aos direitos difusos, coletivos e individuais homogêneos passou-se a exigir uma melhor conscientização do intérprete à aplicação da lei, com certos dogmas do processo, como a coisa julgada, a legitimação e a execução.

A divisão do sistema processual brasileiro ocorre em dois ramos: o processo civil para defesa dos direitos individuais e o processo coletivo para resguardo dos direitos ou interesses difusos, coletivos e individuais homogêneos, tendo como base o Código do Consumidor, Ação Civil Pública, Mandado de Segurança Coletivo e Ação Popular.

A aplicação do princípio da "efetividade do processo" assegura um melhor resultado, tanto na atuação do direito material, como na satisfação integral das pretensões justas do demandante.

A execução do processo civil comum não atende aos reclamos da evolução de nossos tempos, apresentando-se como um entrave numa real concretização do direito.

A execução do processo coletivo ampliou a legitimação, a competência e o relevo das obrigações de fazer ou não fazer, como forma específica de cumprimento dos julgados. Na execução específica atende-se à plenitude da satisfação do julgado, assegurando resultado prático equivalente ao adimplemento.

Conclui-se que é necessária a reforma imediata no processo de execução contra a Fazenda Pública na interpretação que os Tribunais deverão dar ao art. 100 da Constituição.

A justiça contemporânea busca idéias inovadoras em sede processual, que não ofendam os princípios processuais que resguardam a 
legalidade, contraditório, ampla defesa. Enfim, todas as garantias jurisdicionais do Estado Democrático de Direito.

Um reforma processual viabiliza a prestação jurisdicional na medida em que a qualifica para o melhor cumprimento da missão de uniformização da interpretação jurídica, bem como na aplicação democrática do direito, nas quais as exigências devem ser compatíveis com o ideal de justiça.

Cabe ao Estado facilitar o amplo acesso à justiça na garantia da efetividade da jurisdição, relativizando os institutos, forçando os interessados do processo a se adequarem as suas necessidades de forma a concretizar os direitos expostos na lide. Assim, há a garantia de justiça social.

\section{Referências}

ABELHA RODRIGUES, Marcelo. Aç̃os constitucionais. Organizado por Fredie Didier. 3. ed. Salvador: Juspodivm, 2008.

ALMEIDA, Gregório Assagra de. Direito Material Coletivo: superação da summa divisio direito público e direito privado por uma nova summa divisio constitucionalizada. Belo Horizonte: Del Rey, 2008.

BARRETO, Vicente. Interpretação constitucional e Estado democrático de direito. Revista de Direito Administrativo. Rio de Janeiro, jan./mar., 1996.

BARBOSA MOREIRA, José Carlos. Eficácia da sentença e autoridade da coisa julgada. Revista Brasileira de Direito Processual, Uberaba: Vitória Artes Gráficas, n. 32, 2. bimestre,1982.

BARROSO, Luís Roberto. Interpretação e aplicação da constituição. 6.ed. São Paulo: Saraiva, 2008.

BEDAQUE, José Roberto dos Santos. Efetividade do processo e técnica processual. 2. ed. São Paulo: Malheiros, 2007.

CAPPELLETTI, Mauro. Juízes legisladores. Tradução de Carlos Alberto Álvaro de Oliveira. Porto Alegre: Sergio Antônio Fabris Editor, 1993.

CAPPELLETTI, Mauro \& GARTH, Bryant. Acesso à Justiça. Tradução de Ellen Gracie Northfleet. Porto Alegre: Sergio Antônio Fabris Editor, 1988.

CINTRA, Antonio Carlos de Araújo, GRINOVER, Ada Pellegrini, DinAMARCo, Cândido Rangel. Teoria Geral do Processo. 17 ed. São Paulo: Malheiros, 2001. 
DIDIER JUNIOR, Fredie. Curso de Direito Processual civil. Salvador: Juspodivm 2007, v. 4.

DIDIER, Fredie, ZANETI JR., Hermes. Curso de Direito Processual Civil: Processo Coletivo. 3.ed. Salvador: Juspodvm, 2008.

FALCÃO Joaquim Arruda. Cultura jurídica e democracia: a favor da democratização do Judiciário. In.:Direito, cidadania e participação. São Paulo: T. A. Queiroz, 1981.

GONÇALVES, Aroldo Plínio. Técnica Processual e teoria do processo. Rio de Janeiro; Aide, 1992.

GRINOVER, Ada Pellegrini. 0 processo em evolução. 2.ed. Rio de Janeiro: Forense Universitária, 1998.

LEAL, Rosemiro Pereira. Teoria processual da decisão jurídica. São Paulo: Landy. 2002.

LEAL, Márcio Flávio Mafra. Anteprojeto de Código Brasileiro de Processos Coletivos - Aspectos políticos, econômicos e jurídicos. In: Direito processual coletivo e o anteprojeto de código brasileiro de processos coletivos/coordenação: Ada Pellegrini Grinover, Aluisio Gonçalves de Castro Mendes e Kazuo Watanabe. São Paulo: Editora Revista dos Tribunais, 2007.

MACHADO, Fábio Cardoso; AMARAL, Rizzo. Polêmica sobre a ação: a tutela jurisdicional na perspectiva das relações entre direito e processo. Porto Alegre. Livraria do Advogado, 2006.

MACIEL JR., Vicente de Paula. Teoria das ações coletivas: as ações coletivas como ações temáticas. São Paulo: LTr, 2006.

MARINONI, Luiz Guilherme. Técnica Processual e Tutela dos Direitos. 2.ed. São Paulo: Editora Revista dos Tribunais, 2008.

MARINONI, Luiz Guilherme e ARENHART, Sérgio Cruz. Processo de conhecimento. 6. ed. São Paulo: RT, 2006.

MOISES, José Álvaro. Os brasileiros e a democracia. Bases sócio-políticas da legitimidade democrática. São Paulo: Editora Ática, 1995.

PORTO, Sergio Gilberto; USTÁRROZ Daniel. Lições de direitos fundamentais no processo civil: o conteúdo Processual da Constituição Federal. Porto Alegre: Livraria do Advogado Editora, 2009.

OLIVEIRA, Carlos Alberto Alvaro. Efetividade e Processo de Conhecimento. In: Do Formalismo no Processo Civil. 2 ed. São Paulo: Saraiva, 2003. 
ROSA, F.A. de Miranda. Sociologia do Direito: o fenômeno jurídico como fato social. 17.ed. Rio de Janeiro: Jorge Zahar Editor, 2004.

SALLES, Carlos Alberto de. Políticas Públicas e Processo: a questão da legitimidade nas ações coletivas. In: Políticas Públicas: reflexões sobre o conceito jurídico / Maria Paula Dallari Bucci (organizadora). São Paulo: Saraiva, 2006.

SANTOS, Dorival Moreira dos. Anteprojeto do Código Brasileiro de Processo Civil Coletivo: inovações na prática processual em busca de efetividade. In: Direito processual coletivo e o anteprojeto de código brasileiro de processos coletivos/coordenação: Ada Pellegrini Grinover, Aluisio Gonçalves de Castro Mendes e Kazuo Watanabe. São Paulo: Editora Revista dos Tribunais, 2007.

SILVA, José Afonso. Curso de Direito Constitucional Positivo. 21 ed. São Paulo: Malheiros, 2002.

TESHEINER, José Maria Rosa e MILHORANZA, Mariângela Guerreiro. Temas de Direito e Processos Coletivos. Porto Alegre: HS Editora, 2010.

VASCONCELOS. Pedro Carlos Bacelar. Teoria Geral do Controle Jurídico do Poder Público. Lisboa: Edições Cosmos, 1996.

ZAVASCKI, Teori Albino. Processo coletivo: tutela de direitos coletivos e tutela coletiva de direitos. São Paulo: Revista dos Tribunais, 2006.

Recebido: 11/03/2015

Received: 03/11/2015

Aprovado: 12/03/2015

Approved: 03/12/2015 